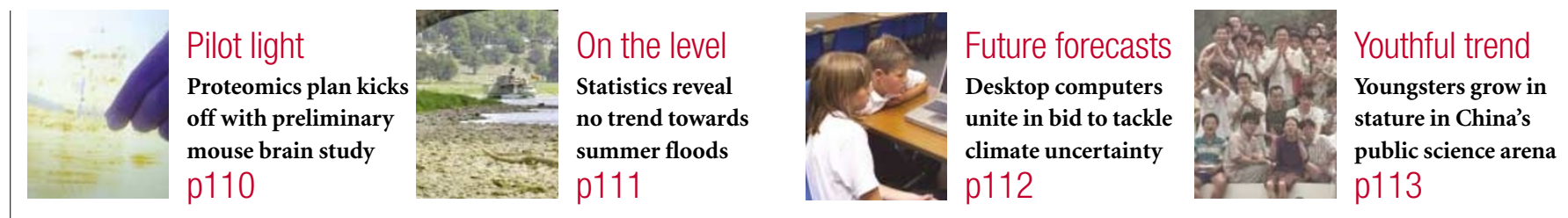

\title{
Agony for researchers as mix-up forces retraction of ecstasy study
}

\section{Jonathan Knight, San Francisco}

Drug researchers are this week hitting out at scientists who accidentally injected monkeys with methamphetamine - or 'speed' - when they were supposed to be studying the effects of the drug ecstasy.

In results published last September, a team at the Johns Hopkins University School of Medicine in Baltimore, Maryland, showed for the first time that repeated small doses of ecstasy damaged brain cells that produce the neurotransmitter dopamine in monkeys (G. A. Ricaurte et al. Science 297, 2260-2263; 2002). Deficiencies in dopamine are linked to neurological disorders including Parkinson's disease. But the researchers will retract their study in this week's issue of Science, after concluding that they injected the wrong drug.

Now critics charge that the team - led by George Ricaurte — was too eager to publish its high-profile finding in this case.

The original study was accompanied by a blaze of publicity in the United States, where it was widely interpreted as evidence that taking ecstasy can lead to brain damage. Johns Hopkins, the National Institute on Drug Abuse (NIDA) in Bethesda, Maryland, which funded the study, and Science's publisher, the American Association for the Advancement of Science (AAAS), each heavily promoted the result. Unusually, Alan Leshner, chief executive of the AAAS and former director of NIDA, publicly endorsed the study, saying: "It sends an important public-health message don't experiment with your own brain."

In their retraction, the authors say that they have been unable to repeat their results. After months of trying to trace the problem, they concluded that all but one of the monkeys had actually received methamphetamine, a powerful stimulant known to damage dopamine-making cells.

The mix-up occurred before the drugs arrived at the lab, the authors say. Similar quantities of the two drugs were ordered and arrived on the same day, their labels apparently reversed. Although the original vial labelled ecstasy has been discarded, tests on the methamphetamine vial show that it contained pure ecstasy, the retraction says.

But the authors should have been suspi-

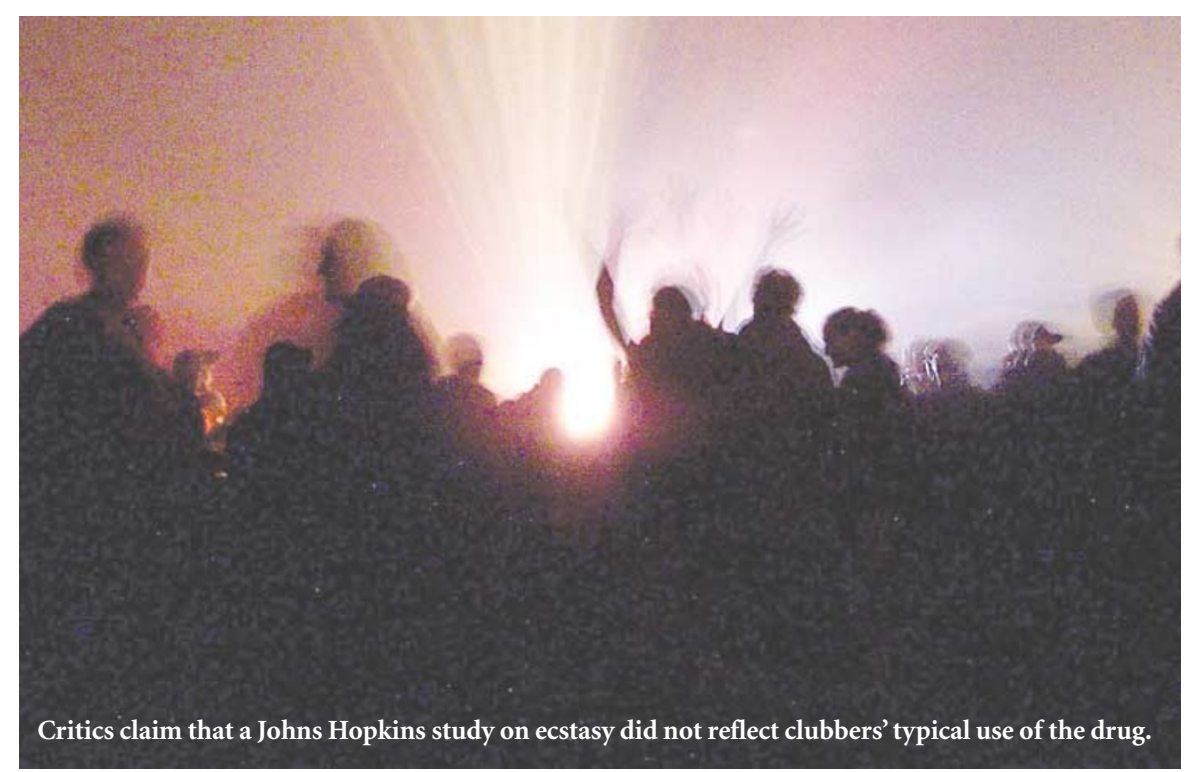

cious sooner, says Charles Grob, a psychiatrist at the Harbor-UCLA Medical Center in Los Angeles who studies ecstasy, also known as MDMA. "It was implausible that MDMA could have caused those findings," he says. Critics have argued that the study, in which the injections resulted in the sudden death of two out of ten monkeys, could not be representative of recreational ecstasy use by people.

Grob and other critics have in the past argued that other studies by Ricaurte, drawing on brain scans, were equally inconclusive. "This is part of a pattern in Ricaurte's work," Grob alleges.

John Henry, a psychoactive-drug researcher at Imperial College, London, characterizes the retraction as a carefully worded plea for more money. He points out that the last sentence leaves open the possibility that the basic result is right, despite failed attempts to repeat the experiment. "It's extremely arrogant," he says. Henry claims that NIDA favours studies that are liable to prove the toxicity of recreational drugs.

Ricaurte could not be reached for comment but his wife and co-author, Hopkins researcher Una McCann, defended the basic hypothesis that ecstasy use can cause Parkinson-like symptoms. She says that it is clearly toxic to dopamine cells in mice, for instance. "We thought we were getting the high levels of dopamine toxicity seen in other species," she says.

Michael Taffe, who studies MDMA at the Scripps Research Institute in La Jolla, California, says that it would have been a tough call whether to publish the original paper, given the potential importance of the finding. Nor would anyone normally test the contents of a labelled bottle from a manufacturer: "I don't know what I would have done," he says.

Ricaurte's group ordered the drugs from NIDA, which supplies approved researchers through a contractor, RTI International of Research Triangle Park, North Carolina. RTI said in a statement that it was reviewing procedures, but has no evidence that it had made a mistake.

NIDA associate director Timothy Condon says that NIDA will assist RTI in the review, but that there would be no further investigation of how the mix-up occurred. "We have asked RTI to look at their procedures," he says. "I don't know what else we could do."

But Grob doubts whether there will be a real attempt to get to the bottom of the episode. "I think NIDA needs to answer some questions," he says. 